\title{
Küçük Güçlü Rüzgâr Santrallerinin Kurulumu ve Şebekeye Etkilerinin Teknik ve Ekonomik Açıdan Değerlendirilmesi: Uygulama Çalışması
}

\author{
Ali Erduman ${ }^{1}$, Ali Durusu ${ }^{2 *}$, Bedri Kekezoğlu² \\ ${ }^{1}$ Hakkari Üniversitesi, Elektrik Elektronik Mühendisliği Bölümü, 30000, Hakkâri, Türkiye \\ ${ }^{2}$ Yıldız Teknik Üniversitesi, Elektrik Mühendisliği Bölümü, 34220, İstanbul, Türkiye \\ *adurusu@yildiz.edu.tr
}

(İlk Geliş Tarihi 1 Mayıs 2018 ve Kabul Tarihi 5 Ağustos 2018)

(DOI: 10.31590/ejosat.420155)

Öz

Fosil enerji kaynakların çevreye vermiş olduğu olumsuz etkiler gün geçtikçe artmaktadır. Bu zararların azaltılması amacıyla yenilenebilir enerji kullanımının artırılmasına yönelik çalışmalarda hız kazanmıştır. Yenilenebilir enerji kaynaklarının şebeke içeresinde kullanımının artması, teknik ve ekonomik açıdan nerede ve nasıl konumlandırılması gerektiği sorusunu beraberinde getirmiştir. Yenilebilir enerji kaynaklarından olan küçük güçlü rüzgâr enerji sistemlerinin dağıtım şebekesi içerisinde ve insanların yaşam alanlarında nasıl konumlandırılacağı da güncel problemlerden bir tanesidir. Yapplan bu çalışmada dağıtım sistemlerinde tüketicinin kendi iç ihtiyaçları için kullandıkları rüzgâr santrallerinin teknik ve ekonomik kurulumu amacıyla örnek bir bölge incelenmiştir. Bununla birlikte kurulan küçük güçlü rüzgâr enerji sistemi üzerinden şebekeye olan etkileri incelenmiş ve elde edilen sonuçlar yönetmeliklerde belirtilen değerler ile karşılaştırılmıştır.

Anahtar Kelimeler: Rüzgâr enerjisi, küçük güçlü rüzgâr türbinleri, enerji dağıtım şebekesi

\section{Installation and Grid Effect Evaluation of Small-Power Wind Power Plant Considering Technical and Economic Criteria: A Case Study}

\begin{abstract}
The adverse effect of fossil energy sources on the environment is increasing every day. In order to decrease the adverse effect, expanding the use of renewable energy resources are encouraged. The increasing use of renewable energy resources in the electrical network has brought together the question of where and how to technically and economically positioned of these plant. It is a current problem that how to integrate the small-power wind power plant to the grid and how to install in the people's living area. In this study, a small-power wind power plant which is used for self-electricity consumption is examined considering technical and economic criteria. Also, grid effect of small-power wind power plant is examined and obtained results are compared with values indicated in the current regulations.
\end{abstract}

Keywords: Wind power, small-power wind power plant, electricity distribution network

\section{Giriş}

Konvansiyonel enerji üretim sistemleri üzerinde kullanılan fosil bazlı yakıtlı çevresel etkilerinin yanında ülkelerin ekonomik ilerlemelerinin önünde de engel oluşturmaktadır (Akella ve ark, 2009). Fosil enerji kaynaklarının oluşturduğu bu problemlerin azaltılması amacıyla insanoğlu yeni enerji üretim araçları üzerine odaklanmış ve özelikle temiz enerji kaynağı olmaları sebebiyle yenilenebilir enerji kaynaklarına yönelmiştir. N.L. Panwar ve arkadaşları tarafindan sunulan gelecek enerji üretim senaryolarına göre yenilenebilir enerji kaynaklarının kullanımının 2040 yılına kadar \%47,7 değerine ulaşabileceği ifade edilmektedir (Panwar ve ark, 2011). Önemli yenilenebilir enerji kaynaklarından biri olan rüzgâr enerjisi sistemlerinin bu artışta önemli bir payı bulunmaktadır. Dünya Rüzgâr Enerjisi Birliği verilerine göre 2016 yılı sonunda dünyada toplam rüzgâr enerjisi kurulu gücü 486,790 GW'a ulaşmış olup 2018-2021 yılları için yapılan tahminlere göre de 230,2 MW'lı rüzgâr santralinin kurulması öngörülmektedir (Council, 2017).

Rüzgâr enerjisi kullanımı lisanslı ve lisanssız olmak üzere iki şekilde gerçekleştirilmektedir. Lisanslı kullanım bağlantılı büyük güçlü enerji santrallerinde ön plana çıkarken, lisanssız kullanım ise sıklıkla dağıtım şebekesi üzerinden bağlı olan tüketicilerin kendi ihtiyaçları için kullanılmaktadır. Dağıtım sisteminde lisansız santrallerin sayısı gün geçtikçe artmaktadır. 2020 yılına kadar 270 MW kurulum değeri ile birlikte lisanssız kullanımın toplamda 1,9 GW değerine ulaşması beklenmektedir (Gsanger, 2017). Lisanssız rüzgâr santrallerin kurulumunda artışın en önemli sebebi ülkelerin bu konuda yapmış oldukları destekleme mekanizmalarıdır. Küçük güçlü rüzgâr santrallerin elektrik üretiminde ülkelere göre destek miktarları Tablo1'de sunulmuştur.

Tablo 1. Küçük güçlü rüzgâr santrallerin ülkelere göre desteklenme fiyatları (Gsanger, 2017) 
European Journal of Science and Technology

\begin{tabular}{|c|c|c|c|c|c|}
\hline Ülke/Bölge & Limit Güç & Destek [€/kWh] & Ülke/Bölge & Limit Güç & Destek $[€ / \mathbf{k W h}]$ \\
\hline \multirow{2}{*}{$\begin{array}{c}\text { Kanada/Nova } \\
\text { Scotia }\end{array}$} & $<50 \mathrm{~kW}$ & 0,34 & \multirow{2}{*}{ Japonya } & $<20 \mathrm{~kW}$ & 0,464 \\
\hline & $>50 \mathrm{~kW}$ & 0,089 & & $>20 \mathrm{~kW}$ & 0,185 \\
\hline \multirow{2}{*}{ Çin } & & \multirow{2}{*}{$0,134-0,201$} & Lüksemburg & & 0,091 \\
\hline & & & Portekiz & $<3,68 \mathrm{~kW}$ & 0,432 \\
\hline \multirow{2}{*}{ Çin Taipei } & $1-20 \mathrm{~kW}$ & 0,237 & Sirbistan & & 0,092 \\
\hline & $>20 \mathrm{~kW}$ & 0,078 & Slovenya & $<1 \mathrm{MW}$ & 0,095 \\
\hline Çek Cumhuriyeti & & 0,071 & İsviçre & $<10 \mathrm{MW}$ & 0,179 \\
\hline \multirow{2}{*}{ Danimarka } & $<10 \mathrm{~kW}$ & 0,33 & \multirow{2}{*}{ İngiltere } & $<50 \mathrm{~kW}$ & 0,097 \\
\hline & $10-25 \mathrm{~kW}$ & 0,2 & & $<100 \mathrm{MW}$ & 0,0635 \\
\hline Yunanistan & $<50 \mathrm{~kW}$ & 0,25 & ABD-Hawaii & $<100 \mathrm{MW}$ & 0,11 \\
\hline İtalya & $<1 \mathrm{MW}$ & 0,3 & $\begin{array}{c}\text { ABD- } \\
\text { Vermont }\end{array}$ & $<15 \mathrm{MW}$ & 0,2 \\
\hline İsrail & $<15 \mathrm{~kW}$ & 0,25 & İsrail & $15-50 \mathrm{~kW}$ & 0,32 \\
\hline
\end{tabular}

\section{Tablo 2. Türkiye'de rüzgâr enerjisi üretim tesislerinde yerli ürün}

kullanılması durumunda verilecek destek miktarları

\begin{tabular}{|l|l|}
\hline Parça & Destek [\$cent/kWh] \\
\hline Kanat & 0,8 \\
\hline Jeneratör ve güç elektroniği & 1 \\
\hline Türbin kulesi & 0,6 \\
\hline $\begin{array}{l}\text { Rotor ve nasel gruplarındaki } \\
\text { mekanik aksamın tamamı }\end{array}$ & 1,3 \\
\hline
\end{tabular}

Rüzgâr santrallerin kurulumun ve yerli üretiminin artmasını teşvik eden bazı ülkeler aynı zamanda rüzgâr santrallerinde kullanılan bileşenleri de parça başına desteklemektedir. Türkiye'de parça başına destek miktarları Tablo 2'de verilmiştir (Resmi Gazete, 2005).

Dağıtım sistemi içerisindeki küçük güçlü rüzgâr santralleri sayısındaki artışla birlikte şebeke üzerinde güç kalitesi, gerilim kararlı̆̆ 1 ve gerilim seviyesinin düzenlenmesi, kayıları, şebeke kapasitesinin verimli kullanılması, güvenirlik vb. konuların yeniden analiz edilmesi gerekmektedir (Barker ve De Mello, 2000). Analizlerin doğru yapılmadığ1 durumlarda gerilim düşümü, gerilim dengesizliği, gerilim yükselmesi, harmonikler ve fliker gibi istenmeyen durumlar ortaya çıkabilmektedir (Taşçıkaraoğlu, 2008; Zehir ve ark, 2017). Lisanssız elektrik üretim sürecinin Türkiye'de yeni yaygınlaşmaya başlaması ile ileride bu muhtemel sorunların ortaya çıkması öngörülmektedir. Dağıtım șebekesi içeresinde bu sorunların oluşmaması amacıyla rüzgâr enerji kaynaklı lisanssız elektrik üretiminin incelenmesi zorunlu kılınmıştır. Öngörülen problemlerin azaltılması amacıyla dağıtım sistemlerinin yapıları ve kurulacak test sistemlerinden elde edilecek sonuçların değerlendirilmesi gerekmektedir (Durusu ve Erduman, 2017).

Küçük güçlü rüzgâr santralleri sıklıkla tüketicinin kendi iç ihtiyaçlarını karşılaması amacıyla kurulmaktadır. Bu durum türbinlerin kuruldukları konumlarını da dikkate almayı gerekmektedir. Özellikle kurulum yapılması planlanan alanda yaşayan insanların rüzgâr türbinlerinin kurulmasından kaynaklı bir risk taşıyıp taşmadığı, rüzgâr türbinlerinin kurulacağı bölgenin toprak yapısının kuruluma uygun olup olmadığ1, rüzgâr türbinlerinin kurulduğu bölgelerin kuşların göç yolu veya konaklama yolu üzerinde olup olmadığı, rüzgâr türbinlerinin askeri veya sivil anten sistemlerine olan uzaklığı, rüzgâr türbinlerinin çevresinde oluşturacağ 1 gürültü değeri vb. bileşenlerin değerlendirilmesi gerekmektedir (Teschner ve Alterman, 2018).

$\mathrm{Bu}$ çalışmanın ikinci kısmında rüzgâr santrallerinin teknik ve ekonomik fizibilite analizine yönelik matematiksel altyapı sunulmuştur. Üçüncü kısımda Bakırköy Belediyesi Botanik Parkı içerisine rüzgâr türbinleri için fizibilite analizi yapılmış ve en uygun türbin tipi belirlenmiştir. Dördüncü bölümde kurulumu tamamlanan sistem üzerinden alınan veriler analizi edilmiş ve standartlar ışığında yorumlanmıştır. Çalışma sonuç bölümü ile sonlandırılmıştır.

\section{Rüzgâr Santrallerinin Fizibilite Analizi}

Rüzgâr türbinlerinin kurulum aşamasından önce teknik ve ekonomik analizlerin gerçekleştirilmesi ve uygun görülmesi durumunda projenin kurulum safhasına geçilmesi, mali kayıpların önlenmesi ile birlikte enerji sisteminin işletiminin kolaylaştırılması açısından önem taşımaktadır. $\mathrm{Bu}$ bölümde rüzgâr santrallerinin kurulum öncesi çalışmalarına ait teorik altyapı sunulmuştur.

\subsection{Rüzgâr santrallerinin teknik analizi}

Rüzgâr santrallerinin teknik fizibilitesinin yapılabilmesi amacıyla ilk olarak türbinlere ait çıkış gücünün belirlenmesi gerekmektedir. Bir rüzgâr türbininden elde edilecek güç miktarı türbinin kurulduğu bölgenin rüzgâr rejimi ile doğrudan ilişkilidir. Bu bağlamda rüzgâr türbinine rüzgâr hızına bağlı çıkış gücü ifadesi denklem (1)'de gösterilmiştir.

$$
P=\frac{1}{2} \rho A v^{3} C_{p}
$$

Burada, $\rho$ hava yoğunlunu $\left(\mathrm{kg} / \mathrm{m}^{3}\right)$, A rüzgâr türbininin süpürme alanını $\left(\mathrm{m}^{2}\right), v$ is rüzgâr hızını $(\mathrm{m} / \mathrm{s})$ ve $C_{p}$ kullanılan rüzgâr türbininin verimini ifade etmektedir. Yatay eksenli rüzgâr türbinlerinde A rüzgâr türbinin süpürme alanı ifadesi denklem (2) yardımıyla elde edilmektedir.

$$
A=\frac{\pi}{4} D^{2}
$$

$\mathrm{Bu}$ ifade de $D$ rotor çapının $\mathrm{m}$ cinsinden ifadesidir. Dolayısı ile süpürme alanın, rotor çapının karesiyle orantılı olarak artmaktadır. Rotor çapı mekanik tasarımın bir sonucu olduğu için güç hesabında önemli bir 
parametredir. Rüzgâr türbinlerin verimi $\left(C_{p}\right)$ rüzgâr türbinlerin yapısına göre değişmekte ve türbinlere göre farklılık göstermektedir. Bu ifadeler türbin üreticileri tarafından her bir rüzgâr hızı için belirlemekte ve sunulmaktadır.

Rüzgâr türbinlerinin teknik fizibilite analizi gerçekleştirilirken türbinin kurulması planlanan bölgeye ait rüzgâr rejiminden yararlanılmaktadır. $\mathrm{Bu}$ amaçla bölgeye ait rüzgâr hızı ölçüm yolu ile ya da hazır veri setleri kullanılarak elde edilmektedir. Buna karşın mevcut veri setinin elde edildiği ölçüm yüksekliği ile incelenen rüzgâr türbinin kule yüksekliği farklılıklar gösterebilmektedir. Yüksekliğe bağlı olarak rüzgâr hızının değişeceği dikkate alındığında yeni yükseklik değeri için rüzgâr hızının yeniden tanımlanması bir zorunluluk halini almaktadır. Buna göre farklı yüksek değerleri için rüzgâr hızı değeri Denklem 3 yardımı ile hesaplanmaktadir.

$$
\frac{V_{h}}{V}=\left(\frac{H_{h}}{H}\right)^{\alpha}
$$

Burada, verilen $V$ anemometrenin ölçüm yaptığı $H$ yüksekliğindeki rüzgâr hızı $(\mathrm{m} / \mathrm{s}), \quad V_{h}$ rüzgâr türbinin kurulum yapıldığı $H_{h}$ yükseklikteki rüzgâr hızı $(\mathrm{m} / \mathrm{s})$ ve $\alpha$ sürtünme katsayısını göstermektedir. Sürtünme katsayısı rüzgâr tribünün kurulduğu bölgede yapılan ölçümler ile elde edilebildiği gibi uzun süreli ölçümlerle de elde edilebilmektedir. Genel olarak Tablo 3'deki değerler kullanılabilmektedir.

Rüzgâr santrali üzerindeki güç çıkışının elde edilmesinden sonra türbinlere ait enerji üretimi Denklemi 4 gösterildiği şekilde $P$ ortalama rüzgâr gücü (W) ve $h$ zaman (saat) ifadeleri kullanilarak hesaplanabilmektedir.

$$
E_{w}=P h
$$

Tablo 3. Yeryüzü Karakteristiklerine göre sürtünme katsayıları (Masters, 2013)

\begin{tabular}{|l|l|}
\hline Yeryüzü Karakteristiği & $\begin{array}{l}\text { Sürtünme } \\
\text { Katsayısı }(\boldsymbol{\alpha})\end{array}$ \\
\hline Pürüzsüz sert toprak, durgun su & 0,10 \\
\hline Toprak seviyesinde uzun çimenli bölge & 0,15 \\
\hline Toprak seviyesinin üzerinde daha uzun mahsul & 0,20 \\
\hline Kırsal orman alanları, birçok ağaç & 0,25 \\
\hline Ağaçlık ufak kasabalar & 0,30 \\
\hline Uzun binalarla dolu büyük şehirler & 0,40 \\
\hline
\end{tabular}

Rüzgâr santrallerinde bölgesel verim kapasite faktörü ile ifade edilmektedir. Türbinden elde edilecek yıllık enerji miktarı kullanılarak kapasite faktörü ifadesi Denklem 5 ile elde edilmektedir (Masters, 2013).

$$
K F=\frac{E_{w}}{P_{R} \times 8760}
$$

Burada $P_{R}$ rüzgâr türbini üreticinsin beyan etmiş olduğu nominal türbin gücünü ifade etmektedir.

\subsection{Rüzgâr santrallerinin ekonomik analizi}

Rüzgâr türbinlerinin ekonomik analizi noktasında en önemli parametre yapılan yatırımın geri dönüşs süresidir. Yatırım maliyeti $C$, ve üretilen enerjinin satış bedeli $\mathrm{C}_{\mathrm{E}}$ kullanılarak projeye ait geri dönüş süresi Denklem 6 'da gösterildiği şekilde hesaplanabilmektedir.
$\mathrm{GDS}=\frac{C}{E_{w} \cdot \mathrm{C}_{\mathrm{E}}}$

\section{Küçük Güçlü Rüzgâr Enerji Sistemi Fizibilite Analizi}

Gerçekleştirilen çalışma kapsamında İstanbul'a kurulacak küçük güçlü rüzgâr türbinlerine ait fizibilite analizi gerçekleştirilmiştir. Bu kapsamda ilk olarak gölge özellikleri irdelenmiş, buna bağlı olarak farklı rüzgâr türbini seçenekleri değerlendirilmiştir.

\subsection{Bölge özellikleri}

Bu çalışmada Marmara bölgesi İstanbul ili Bakırköy ilçesi sınırları içeresindeki Bakırköy Botanik Parkı ele alınmış ve rüzgâr potansiyeli incelenmiştir. Şekil 1'de, 40,9983 K, 28,87707 D koordinatlarında ve deniz seviyesinden 49 m yükseklikte bulunan Bakırköy Botanik Parkın yerleşimi verilmiştir.

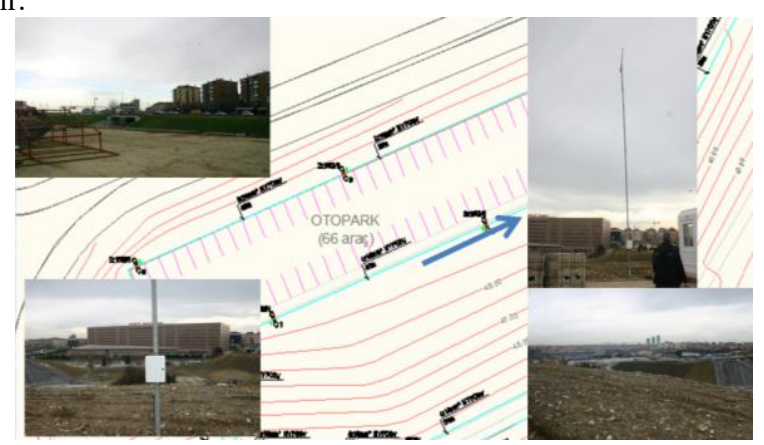

Şekil 1. Bakırköy Botanik parkı rüzgâr türbini kurulum alanı

Fizibilite analizinin gerçekleştirilebilmesi amacıyla ile olarak bölgenin rüzgâr profilinin tespit edilmesi için rekreasyon alanının en yüksek noktasına direk yüksekliği 12 m olan ATLANTISS RHY08 marka bir rüzgâr ölçüm sistemi kurulmuştur. Bölgenin rüzgâr verileri ölçülmüş ve ölçüm sonucunda hâkim rüzgâr yönünün kuzeydoğu, otalama rüzgâr hızının 12 metre yükseklikte $3,8 \mathrm{~m} / \mathrm{s}$ olduğu tespit edilmiştir. Şekil 2'de bölgenin rüzgâr dağılımı histogramı, rüzgâr yönü ve rüzgâr hızı esme olasılığ1 gösterilmiştir.

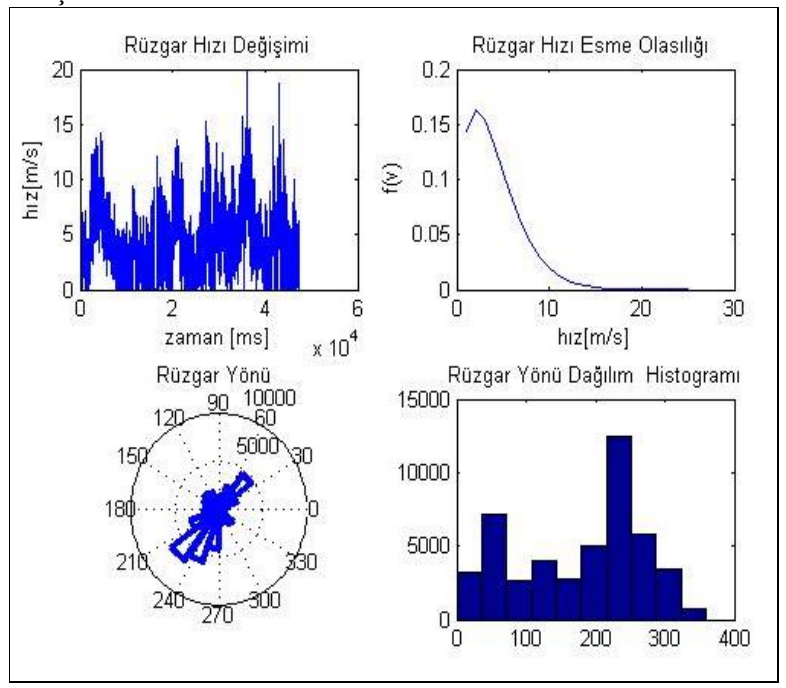

Şekil 2. Bakırköy Botanik Park alanın genel rüzgâr dağllım bilgileri 


\section{European Journal of Science and Technology}

Bölgenin pürüzlülük oranı LUTRON marka El anemometresi ve ATLANTİS RHY08 marka bir rüzgâr ölçüm sistemi ile eş zamanlı yapılan ölçümler ile 0,365673 olarak tespit edilmiştir. Elde edilen değerin literatürde tanımlanan değerlere yakınsadığı görülmüştür. Kurulum yapılacak bölge konum itibariyle yoğun yerleşim alanıdır. Rekreasyon alanı bir fazlı ve üç fazlı yüklerden oluşmaktadır. Rekreasyon alanındaki elektriksel yük profili Tablo 4'de verilmiştir.

Tablo 4. Bakırköy Botanik Parkı elektriksel yük dağılımı

\begin{tabular}{|c|c|c|c|}
\hline Tip & Adet & Güç [W/adet] & Toplam Güç [ W] \\
\hline Aydınlatma & 66 & 35 & 2310 \\
\hline Aydınlatma & 26 & 150 & 3900 \\
\hline Aydınlatma & 33 & 300 & 9900 \\
\hline Aydınlatma & 70 & 440 & 30800 \\
\hline Aydınlatma & 7 & 1600 & 11200 \\
\hline Motor & 18 & 4097 & 73746 \\
\hline
\end{tabular}

Rüzgâr türbinlerinin kurulması planlanan bölgeye ait basitleştirilmiş tek hat diyagramı Şekil 3'de sunulmuştur. Tablo 4 'deki yükler tek hat şeması üzerinde tek bir yük olarak gösterilmiştir. Dağıtım şebekesine 1 MVA ve 34,5/0,4 kV'luk transformatör üzerinden bağlantının yapılması öngörülmüştür.

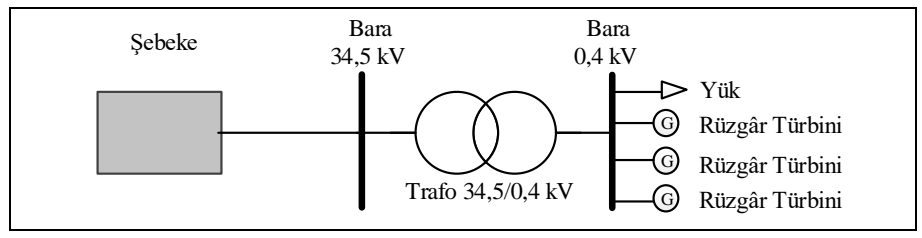

Şekil 3. Parka ait elektrik tek hat şeması

\subsection{Rüzgâr Türbinlerin Şebekeye Paralel Bağlantı Şartları}

Rüzgâr santrallerinin güçlerine göre şebekeye bağlantı noktaları ve şebekeye etkileri farklık göstermektedir. Bu etkilerin minimize edilmesi için şebekeyle paralel bağlantı, elektriksel koruma ve kontrolü ile şebekeye paralel çalışma durumu TS EN 50438 standardında belirtilen şartlarla düzenlenmiştir (TS EN 50438, 2015). Ayrıca, küçük güçlü rüzgâr türbinlerin lisansız elektrik üretimi amacıyla kullanımı, 10 Mart 2012 tarihinde 8229 Sayı ile yayınlanan Elektrik Piyasasında Lisanssız Elektrik Üretimine İlişkin Yönetmeliğin Uygulanmasına Dair Tebliğin Bağlantı Kriterlerinin 14. maddesinde ve 15. maddesinde tanımlanan özelliklere göre tanımlanmıştır. Gerçekleştirilen bu çalışmada da yukarıda sıralanan yasal düzenlemeler dikkate alınmış ve analizler bu çerçevede gerçekleştirilmiştir.

\subsection{Rüzgâr Türbinlerinin Seçimi ve Yerleşimi}

Çalışma kapsamında incelenen bölge üzerine kurulabilecek 2,4 -50 kW güç aralığında 8 farklı rüzgar türbine ait teknik ve ekonomik analizler gerçekleştirilmiştir. Rüzgâr türbini seçimi amacı ile türbinlerinin mekanik yapısı, şebeke bağlantısı tipi, üretim kapasitesi, kurulum maliyeti, kapasite faktörü, temin süresi ve görsel yapısı gibi özelikleri dikkate alınmıştır (Bahaj ve ark, 2007). Çalışma kapsamında dikkate alınan rüzgâr türbinlerinin üretim eğrileri Şekil 4'te ve teknik özellikleri Tablo 5'de gösterilmiştir.
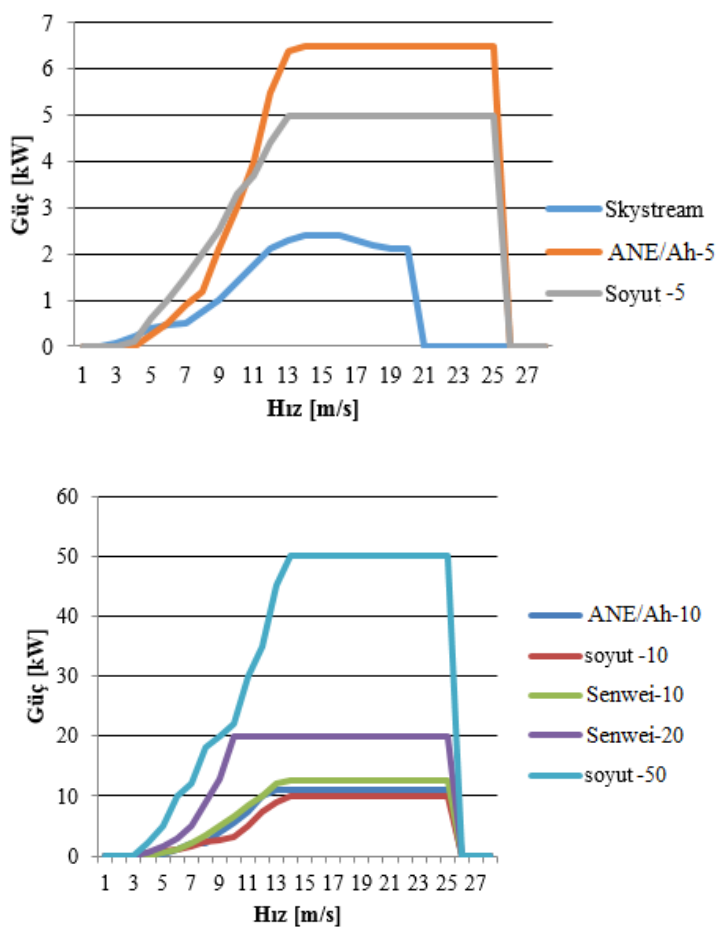

Şekil 4. Rüzgâr türbinlerin güç üretim eğrileri

Çalışma kapsamında ele alınan rüzgâr türbinlerine ait çıkış güçleri bölge üzerinden elde edilen rüzgâr verileri kullanılarak elde edilmiştir. 12 m'de ölçülen rüzgâr hızları çalışmada kullanılan ticari rüzgâr türbinlerinin kule yüksekliklerine göre yeniden düzenlenmiştir. Rüzgâr hızlarına göre rüzgâr türbinlerinin üretebilecekleri güç değerlerini hesaplamak amacıyla Matlab Paket Programı kullanılmıştır. Buna göre örnek olarak Skystream rüzgâr türbinine ait hesaplan güç çıkış eğrisi Şekil 5'te gösterilmiştir.

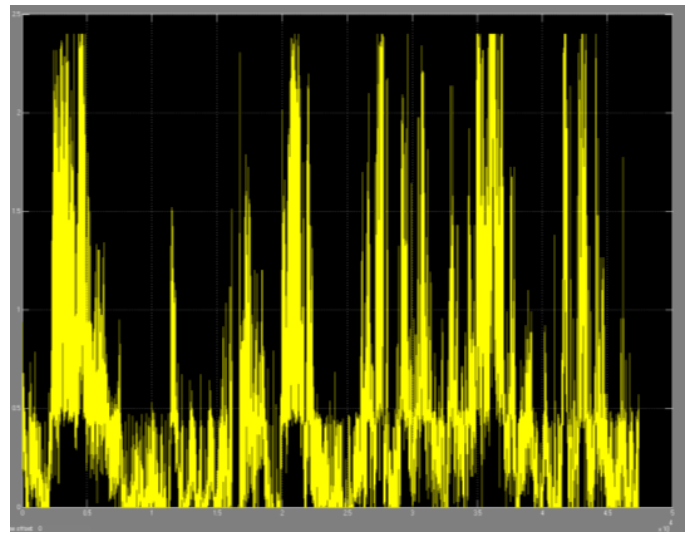

Şekil 5. Skystream rüzgâr türbininin güç çıkışı değişimi

Tablo 5. 2,4 -50 kW arasında sekiz farklı ticari rüzgâr türbinin teknik özelliklerinin karşılaştırılması 
Avrupa Bilim ve Teknoloji Dergisi

\begin{tabular}{|c|c|c|c|c|c|c|c|c|}
\hline Model & Skystream & ANE/Ah-5 & ANE/Ah-10 & Soyut-5 & Soyut-10 & Soyut-50 & Senwei-10 & Senwei-20 \\
\hline Rotor çapı [m] & 3,72 & 5,4 & 7,6 & 5,82 & 8,23 & 8,12 & 8 & 12,35 \\
\hline Nominal güç $\left(\mathbf{P}_{\max }\right)[\mathrm{W}]$ & 2400 & 5000 & 1000 & 5000 & 10000 & 50000 & 10000 & 20000 \\
\hline Nominal rüzgâr hızı $[\mathrm{m} / \mathrm{s}]$ & 13 & 11 & 12 & 12 & 12 & 12 & 10,8 & 9 \\
\hline Çalışma rüzgâr hızı aralığı [m/s] & $3-25$ & $3-30$ & $3-30$ & $3-25$ & 3.25 & $3-35$ & 3-35 & $3-35$ \\
\hline Devreye girme hızı $[\mathrm{m} / \mathrm{s}]$ & 2 & 2 & 2,5 & 3 & 3 & & 2 & 3 \\
\hline Çalışma gerilimi [V] & 220VAC & $\begin{array}{c}\text { DC500V/DC } \\
240 \mathrm{~V} / \mathrm{AC} 22 \\
0\end{array}$ & AC380 & $\begin{array}{c}12-24-48 \mathrm{~V} \\
\text { DC }\end{array}$ & $\begin{array}{c}12-24- \\
48 \mathrm{~V} \text { DC }\end{array}$ & AC380 & $\begin{array}{c}\text { DC240V/5 } \\
00 \mathrm{~V}, \\
\mathrm{AC} 220 \mathrm{~V} / 3 \\
80 \mathrm{~V}\end{array}$ & $\begin{array}{l}\mathrm{AC} 220 \mathrm{~V} / 3 \\
80 \mathrm{~V}\end{array}$ \\
\hline Kule yüksekliği [m] & 24 & 8 & 12 & $12-15$ & $12-15$ & $20-25$ & 16 & 16 \\
\hline
\end{tabular}

Hesaplanan güç eğrileri kullanılarak elde edilen enerji üretim miktarlarının nominal üretilebilecek enerjiye oranlaması yapılarak rüzgâr türbinlerine ait kapasite faktörü tespit edilmiştir. Yapılan ekonomik analizde geri dönüş süresinin hesaplanması amacıyla enerji satış fiyatı 0,3 $\mathrm{kWh} / \mathrm{TL}$ olarak alınmıştır. Rüzgâr türbinlerinin maliyet, kapasite faktörü ve geri dönüşüm süresi karşılaştırılmasına ilişkin elde edilen sonuçlar Tablo 6'da sunulmuştur.

Yapılan analizler sonucunda, geri dönüşüm yılı en kısa olan seçenek Senwei $20 \mathrm{~kW}$ rüzgâr türbini olurken geri dönüşümü en uzun olan seçenek Soyut $10 \mathrm{~kW}$ rüzgâr türbini olarak tespit edilmiştir. TS EN 50438 standardında belirtilen şartlara ve enerji üretimi kısıtları birlikte dikkate alındığında bölgeye büyük güçlü rüzgâr türbinleri yerine gücü $3,5 \mathrm{~kW}$ altında bir türbinin bağlanmasının daha uygun olacağı görülmüştür. Buna göre bölge üzerine Skystream $2,4 \mathrm{~kW}$ rüzgâr türbinlerinin kurulmas1 kararlaştırılmıştır. Bölgede görsel etki ve farkındalık yaratması amacıyla her bir faza bir adet olmak üzere üç adet rüzgâr türbini kurulumu yapılmıştır.

\section{Kurulum Sonrası Şebekeye Etkilerin Analizi}

Çalışma kapsamında fizibilitesi gerçekleştirilen rüzgâr türbinlerinin kurulumu tamamlanmış ve kurulum sonrası türbinlerin şebekeye etkileri ilgili yönetmelikler kapsamında değerlendirilmiştir. Bu amaçla türbinlerin bağlantı noktalarından güç analizörleri yardımıyla TS EN 50160/AC (2013) standardına göre bir hafta boyunca $10 \mathrm{dk}$. aralıklar ile eş zamanlı olarak ölçümler yapılmıştır. Ölçümlerde eş zamanlı akım gerilim, güç, enerji, fliker, ana ve ara harmonikler, gerilim dengesizlikleri, vb. güç kalite parametrelerinin tamamı incelenmiş ve elde edilen ölçüm sonuçları Tablo 7 'de verilmiştir. Yapılan ölçümler sırasında 1. ve 3. faza bağlı olan rüzgâr türbinler üzerinden gerçekleştirilmiştir.

Tablo 6. Farklı Ticari rüzgâr türbinlerin maliyet ve geri dönüşüm yılları bazında karşılaştırılması

\begin{tabular}{|c|c|c|c|c|c|}
\hline Türbin Tipi & $\begin{array}{c}\text { Güç } \\
{[\mathbf{k W}]}\end{array}$ & $\begin{array}{c}\text { Kule } \\
\text { yüksek. } \\
{[\mathbf{m}]}\end{array}$ & Maliyet & KF & $\begin{array}{c}\text { GDS } \\
{[\mathbf{y l l}]}\end{array}$ \\
\hline Skystream & 2,4 & 30 & $7300[€]$ & 0,18 & 11 \\
\hline ANE/Ah-5 & 5 & 30 & $25000[\$]$ & 0,14 & 19 \\
\hline ANE/Ah-10 & 10 & 30 & $40000[\$]$ & 0,13 & 20 \\
\hline
\end{tabular}

www.ejosat.com ISSN:2148-2683

\begin{tabular}{|c|c|c|c|c|c|}
\hline Soyut-5 & 5 & 12 & $15500[\$]$ & 0,10 & 23 \\
\hline Soyut-10 & 10 & 15 & $21000[\$]$ & 0,06 & 25 \\
\hline Soyut-50 & 50 & 25 & $120000[\$]$ & 0,16 & 13 \\
\hline Senwei-10 & 10 & 30 & $40000[\$]$ & 0,23 & 11 \\
\hline Senwei-20 & 20 & 30 & $52000[\$]$ & 0,29 & 10 \\
\hline
\end{tabular}

Kurulumu tamamlanan ve işletmeye alınan sistem üzerinden alınan ölçüm sonuçları TS EN 50438 çerçevesinde değerlendirilmiştir. Elde edilen sonuçlara göre sistem üzerinde harmonik ve fliker değerlerinin limitler dahilinde kaldı ̆̆ 1 , benzer şekilde gerilim değişiminin de izin verilen sınırlar dahilinde olduğu gözlemlenmiştir.

Tablo 6. Bakırköy parkında 02.12.2013 ve 09.12.2013 tarihleri arasında yapılan ölçümler

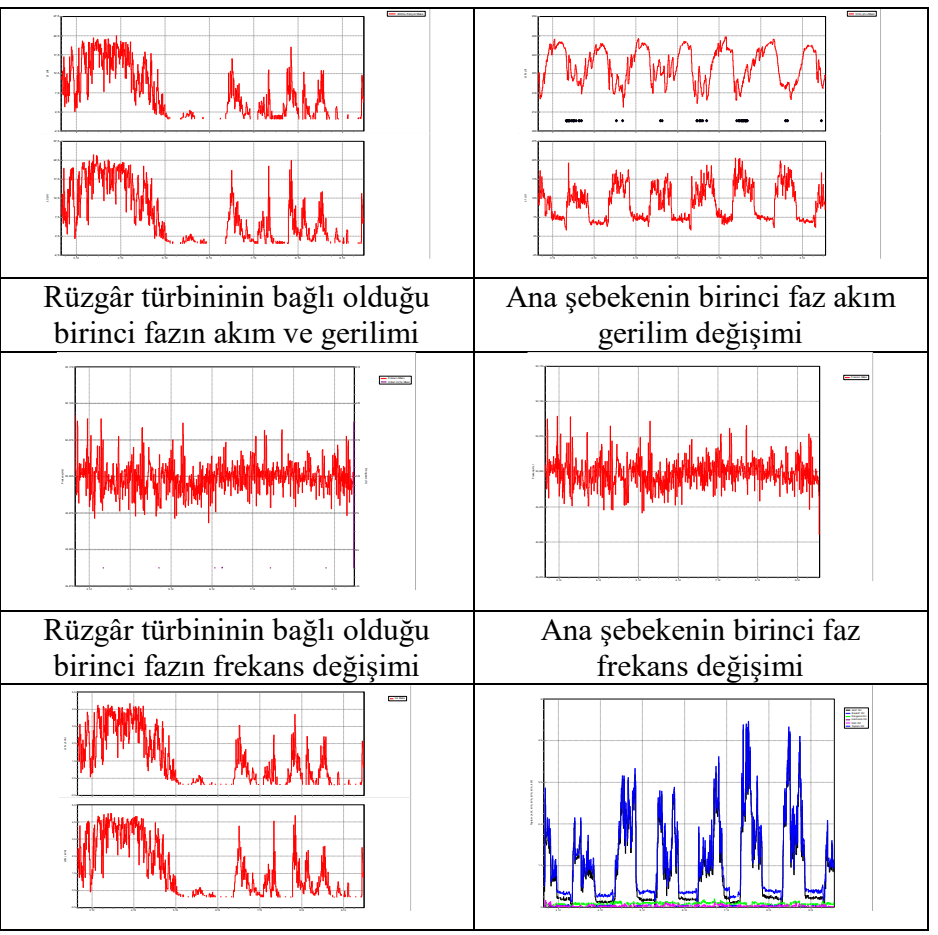


European Journal of Science and Technology

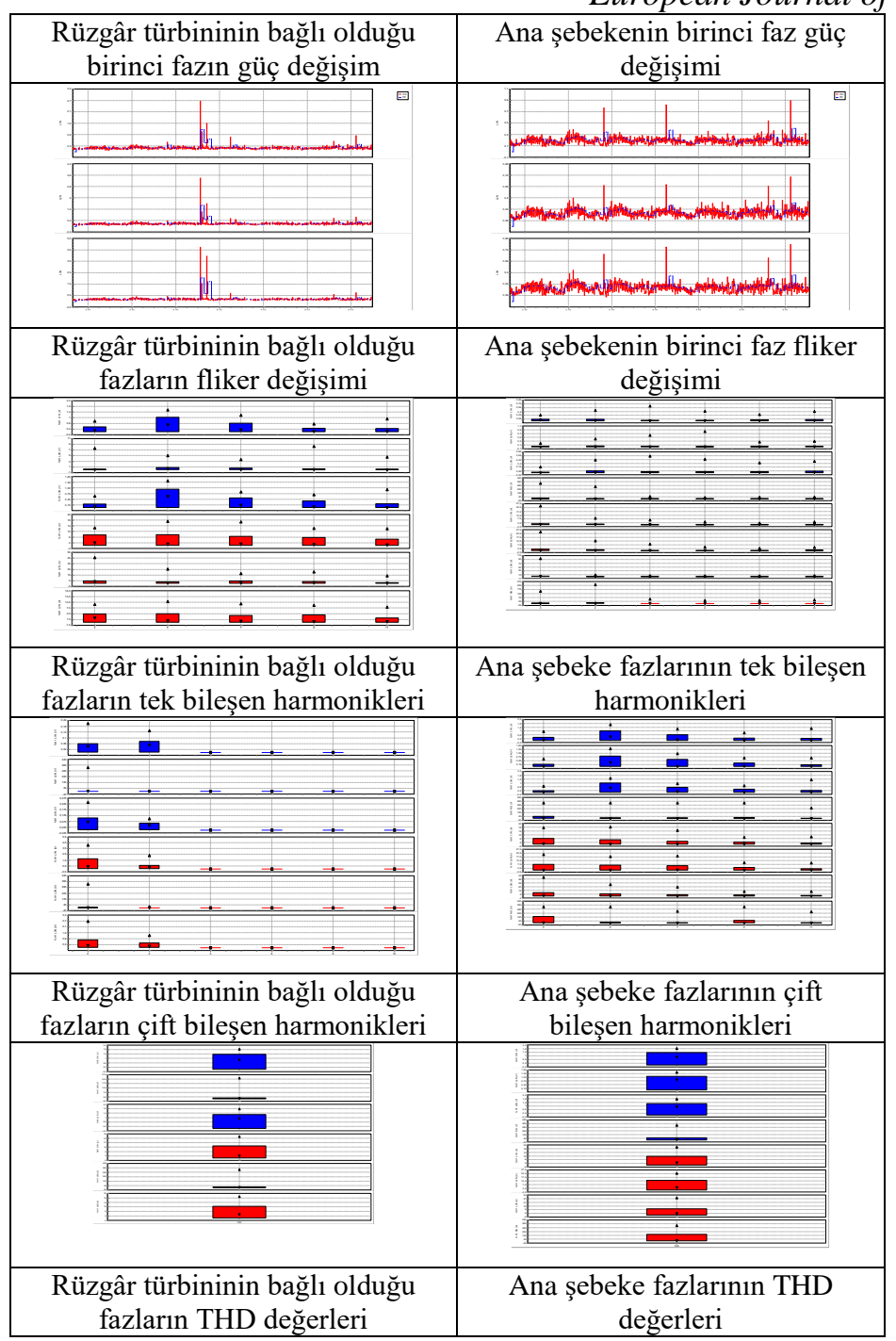

\section{Sonuç ve Öneriler}

Gerçekleştirilen çalışma kapsamında İstanbul Bakırköy İlçesinde bulunan Bakırköy Botanik Parkı'na kurulması planlanan rüzgâr türbinlerine ait teknik ve ekonomik fizibilite çalışması gerçekleştirilmiştir. $\mathrm{Bu}$ kapsamda ilk olarak bölgenin rüzgâr potansiyeli irdelenmiş ve rüzgâr hızının düşük olmasına bağlı olarak büyük güçlü rüzgâr türbini kurulumuna uygun olmadığ gözlemlenmiştir. Buna bağlı olarak belirlenen 8 farklı rüzgâr türbini içerisinden bölgeye en uygun olanına yapılan teknik ve ekonomik analizler neticesinden karar verilmiştir. Belirlenen türbinin kurulum safhasından sonra sisteme olan etkisi yapılan ölçümler ile gözlemlenmiştir. İlgili standartlar çerçevesinden ölçüm sonuçlarının değerlendirilmesi ile tüm limit değerlerin sağlandığı görülmüştür. Gerçekleştirilen proje ile ilgili bölgedeki enerji ihtiyacının bir kısmının sağlanmasının yanında toplumun yenilenebilir enerji kaynakları konusunda bilinçlendirilmesine de katkı sağlanmıştır.

\section{Kaynaklar}

Akella, A.K., Saini, R.P. ve Sharma, M.P., Social, economical and environmental impacts of renewable energy systems. Renewable Energy, 2009. 34(2): p. 390-396.
Panwar, N.L., Kaushik, S.C. ve Kothari, S., Role of renewable energy sources in environmental protection: A review. Renewable and Sustainable Energy Reviews, 2011. 15(3): p. 1513-1524.

Council, G.W.E., Global Wind Report Annual Market Update 2016. 2017.

Gsänger, J.-D.P.A.S., 2017 Small Wind World Report Summary. 2017.

Resmi Gazete, Kanun No: 5346, Yenilenebilir enerji kaynaklarinin elektrik enerjisi üretimi amaçli kullanimina ilişkin kanun. 2005.

Barker, P.P. ve De Mello, R.W., Determining the impact of distributed generation on power systems. I. Radial distribution systems. in Power Engineering Society Summer Meeting, 2000. IEEE. 2000. IEEE.

Taşcıkaraoğlu, A., Rüzgar türbinlerinin gü̧̧ kalitesi üzerine etkilerinin modellenmesi. Y.Lisans Tezi, Yıldız Teknik Üniversitesi, 2008.

Zehir, M.A., et al., Impacts of microgrids with renewables on secondary distribution networks. Applied Energy, 2017. 201(Supplement C): p. 308-319.

Durusu, A. ve Erduman, A., Feasibility Analysis, Installation and Grid Effect of Small Size Wind Energy Plant: A Case Study of Bakirkoy Botanical. in IV. International Multidisciplinary Eurasian Congress, Rome, 2017.

Teschner, N.A. ve Alterman, R., Preparing the ground: Regulatory challenges in siting small-scale wind turbines in urban areas. Renewable and Sustainable Energy Reviews, 2018. 81(Part 2): p. 1660-1668.

Masters, G.M., Renewable and efficient electric power systems. 2013: John Wiley \& Sons.

Türk Standarları Ensititüsü, TS EN 50438, Mikro jeneratörlerin alçak gerilim dağıtım şebekelerinde paralel olarak bağlanması için kurallar, 2015.

Bahaj, A.S., Myers, L. ve James, P.A.B., Urban energy generation: Influence of micro-wind turbine output on electricity consumption in buildings. Energy and Buildings, 2007. 39(2): p. 154-165.

Türk Standartları Enstitüsü, TS EN 50160, Genel elektrik şebekeleri tarafindan săglanan elektriğin gerilim karakteristikleri, 2013. 